\title{
MODELS OF SHIPS GROUDINGS ON COASTALS AREAS
}

\section{MODELE WEJŚCIA NA MIELIZNE NA AKWENACH PRZYBRZEŻNYCH}

\author{
Marcin Przywarty \\ Maritime University, Institute of Marine Traffic Engineering \\ Akademia Morska, Instytut Inżynierii Ruchu Morskiego \\ 70-500 Szczecin Wały Chrobrego 1-2 \\ e-mail: mprzywarty@am.szczecin.pl
}

\begin{abstract}
The paper presents description of models of ships groundings probability assessment on coastal areas. It also presents assumptions and preliminary results of new grounding model developed in Maritime University in Szczecin. This model was used in stochastic simulation model of comprehensive navigational safety assessment.
\end{abstract}

Keywords: grounding model, fault tree, Bayesian methods, geometric probability

Streszczenie: W artykule przedstawiono opis modeli pozwalających na określanie prawdopodobieństwa wejścia statku na mieliznę na akwenach przybrzeżnych. Przedstawiono również założenia, budowę oraz wstępne wyniki nowego modelu wejścia statku na mieliznę opracowanego w Akademii Morskiej w Szczecinie. Model ten zastosowany został $\mathrm{w}$ stochastycznym symulacyjnym modelu do kompleksowej oceny bezpieczeństwa nawigacyjnego.

Slowa kluczowe: model wejścia na mieliznę, drzewo uszkodzeń, metody bayesowskie, prawdopodobieństwo geometryczne 


\section{MODELS OF SHIPS GROUDINGS ON COASTALS} AREAS

\section{Introduction}

Sea transport development cause the increase of the intensity of ships traffic and ships dimensions. Increasing risk of maritime accidents has caused the development of models of navigational safety assessment. Probability of the ships groundings is one of the most important factors influencing on the navigational safety. The main types of the models of the probability of ships grounding assessment are the models based on:

- fault trees

- Bayesian methods

- geometric probability

\section{Models of ships groundings on coastal areas}

\subsection{Fault tree}

Development of a fault tree starts from the fault (grounding). In the next stages all possible events leading to the grounding are taken into consideration. In the each level of the fault tree general causes of groundings should be determined as broad as it is possible. This process should be continued until it can be stated that it is possible to estimate the probabilities of elementary events. General scheme of grounding fault tree is presented in figure 1.

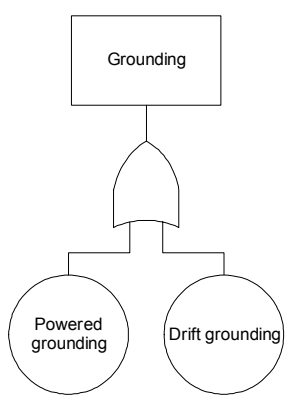

Fig. 1. General scheme of the grounding fault tree 
Powered grounding fault tree is presented in figure 2. It can be stated that powered groundings are caused mainly by errors made in the track planning or by errors in execution of a desired track.

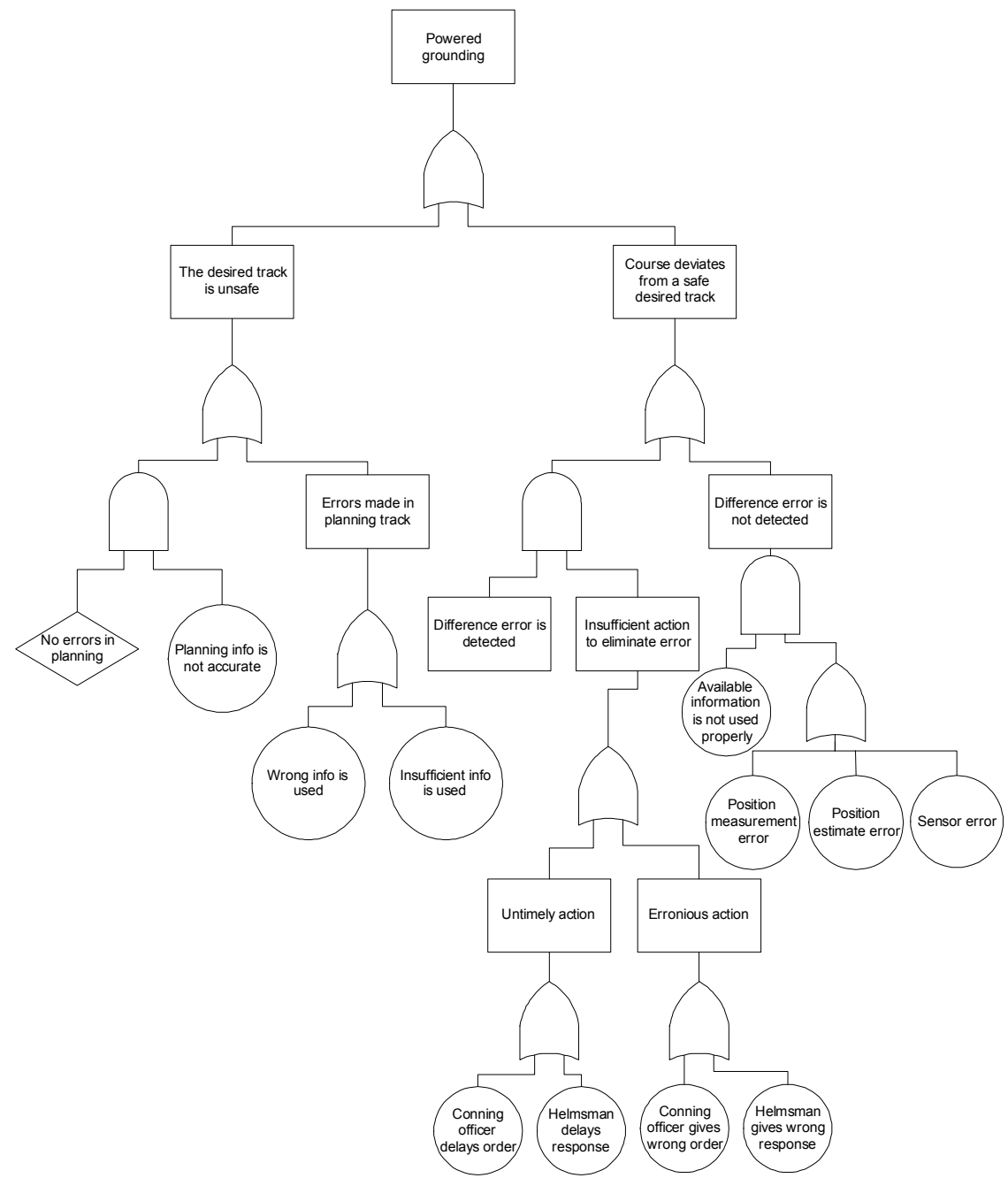

Fig. 2. Powered grounding fault tree [1]

Drift grounding fault tree is presented in figure 3. All of the following conditions must be present in order to drift grounding can occur [1]:

- Unsafe wind and/or current - prevailing conditions exert such force on the vessel that she is drifted towards a grounding hazard. 
- Assistance failure - the assistance is not requested or the assistance fails to tend vessel away from a grounding hazard.

- Anchor failure - the anchor is not considered or anchor is unable to prevent the vessel from a tending towards grounding hazard.

- Lost of steerage way - the vessel is unable to proceed with directional stability due to either a loss of steering or propulsion.

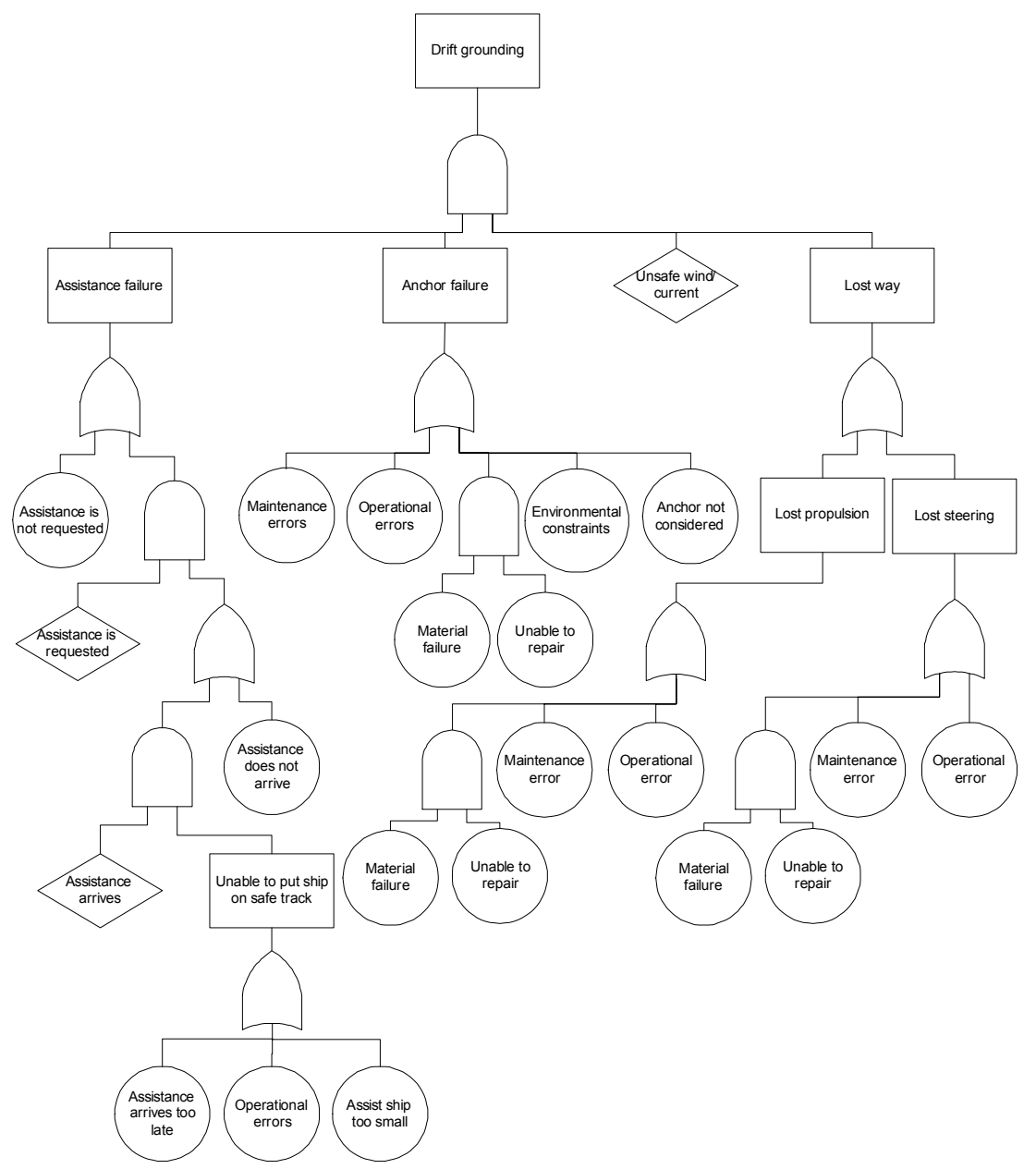

Fig. 3. Drift grounding fault tree

To estimate the probability of grounding: first the probabilities of elementary events should be calculated; next the probabilities of events on 
the higher levels should be calculated and finally the probability of grounding should be estimated.

\subsection{Model based on Bayesian methods}

The general thesis of model is that the probability of grounding on particular transit depends on a set of risk factors or explanatory variables. Formally, the model can be described as follows: let $\mathrm{G}$ denote the event that a transit results in a grounding, and let $X=\left(X_{1}, X_{2}, X_{3}, \ldots, X_{p}\right)$ be the vector of explanatory variables. These variables may be categorical (including binary) or continuous. The model attempts to estimate the conditional probability of $\mathrm{G}$ given a specified value $\mathrm{x}$ of $\mathrm{X}$ [4]. This probability is given by:

$$
p(G \backslash x)=\frac{l(x \backslash G) p}{l(x \backslash G) p+l(x \backslash S)(l-p)}
$$

where $\mathrm{p}$ is the unconditional probability of $\mathrm{G}$ and where $1(\mathrm{x} \mid \mathrm{G})$ and $1(\mathrm{x} \mid \mathrm{S})$ are the likelihoods of $x$ given $G$ and $S$, respectively. $S$ denotes the event that the transit is completed safely.

To estimate the probability of grounding, it is necessary to select a set of explanatory variables [3] and to estimate the unconditional grounding probability $\mathrm{p}$ and likelihoods $1(\mathrm{x} \mid \mathrm{G})$ and $\mathrm{l}(\mathrm{x} \mid \mathrm{S})$. The vector of explanatory variables must capture the attributes of the transit that can be expected reasonably to contribute to the likelihood of grounding. These attributes might include, among others [4]:

- vessel characteristics (draft, beam, maneuverability),

- topography of the waterway (water depth, channel width, channel length, complexity of turns, traffic density),

- environmental conditions (wind, visibility, currents, waves),

- operators (experience with the vessel, training, local knowledge),

- information available to operators (quality of charts, quality of information about tide levels and currents, VTS guidance, navigation aids).

Values of explanatory variables can be estimated on the basis of statistical data. 


\subsection{Model based on geometric probability}

The model of grounding was developed with assumption that probability of accident is dependant of distance to the given safety contour (or shore). The probability of grounding can be described by following formula:

$$
P_{G r}=P_{G} P_{H}
$$

where $\mathrm{P}_{\mathrm{Gr}}$ is a probability of grounding, $P_{G}$ is a geometrical probability and $P_{H}$ is a probability of human error.

Geometrical probability is calculated on the basis of observation of real traffic. To describe traffic nearby navigational obstacles the special mixed distribution could be used (Fig. 4). This distribution is the mixture of two normal distributions with mean equals zero.

$$
f(x)=\frac{1}{\sigma \sqrt{2 \pi}} \exp \frac{1}{2}\left(\frac{x}{\sigma}\right)^{2} \text { where: } \sigma=\left\{\begin{array}{lll}
\sigma_{r} & \text { if } & x>0 \\
\sigma_{l} & \text { if } & x<0
\end{array}\right.
$$

where $\sigma_{r}$ is a standard deviation of the right side of distribution $\sigma_{l}$ is a standard deviation of the left side of the distribution.

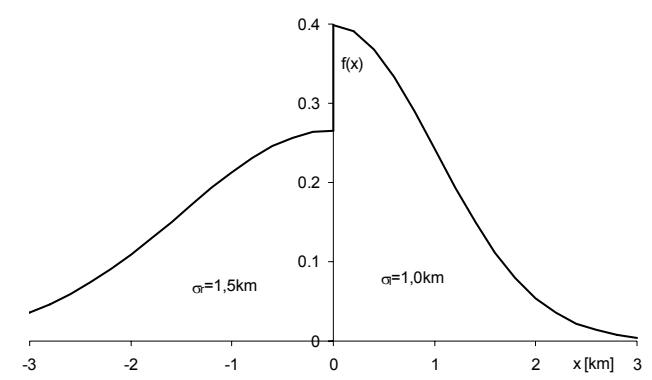

Fig. 4. Ships traffic distribution (mixture of two normal distributions)

The studies on ships traffic carried out on the Baltic Sea (real traffic) and on the restricted area (simulation studies) lead to assumption that standard deviation of ships traffic is mostly dependent from distance to the danger 
and size of ships. Following relation could be used to define the standard deviation of ships routes:

$\sigma=a D+b$

where $a$ and $b$ are coefficients of regression, $D$ is distance to navigational danger (safety contour, isolated depth).

The factor $a$ is dependant of ships size and type. In the researches this factor was represented by ships length $(L)$. The factor $a$ is around 0.1 and its dependence of ships length $L$ could be expressed as:

$a=-0.0002 L+0.12$

The factor $b$ varies from 450 to 550 and was estimated as mean value as 500 . The typical behaviour of ships traffic near the Bornholm is presented in figure 5. The behaviour of traffic is very similar to proposed approach with using two different normal distributions.

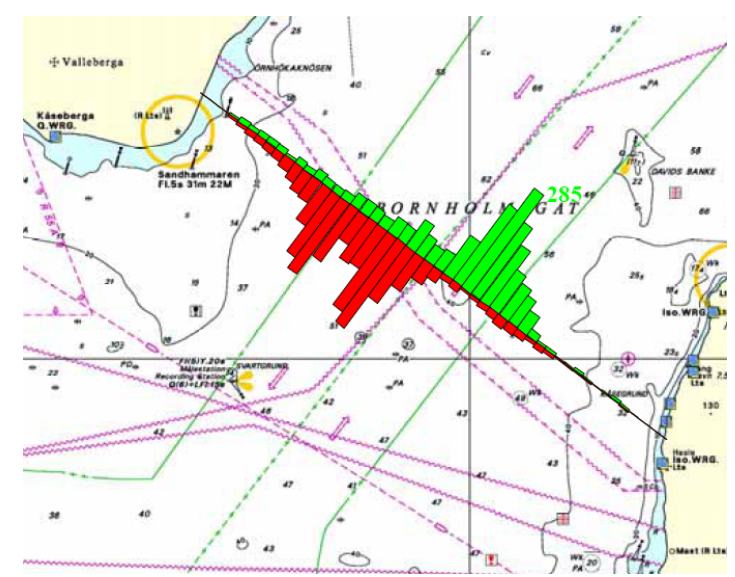

Fig. 5. Distribution of ships traffic, real data from AIS

Probability of human error is estimated on the level $P_{H}=1 * 10^{-4}$ which is the standard value assumed in human reliability assessment confirmed in several maritime studies [2] for grounding assessment.

Finally the probability of grounding accident $P_{G r}$ is evaluated by the following formula: 


$$
P_{G r}=P_{G r L}+P_{G r R}
$$

where $P_{G r L}$ is a probability of grounding on the left side of the waterway and $P_{G r R}$ is a probability of grounding on the right side of the waterway

This probability of grounding was used in the further Monte Carlo simulations. Exemplary results of these researches are presented below.

\section{Exemplary results of grounding model used in Monte Carlo simulation}

The goal of the researches was to estimate intensity and simulated positions of ships groundings on the Southern Baltic area. Simulation was carried out by means of stochastic model of navigational safety assessment (fig. 6).

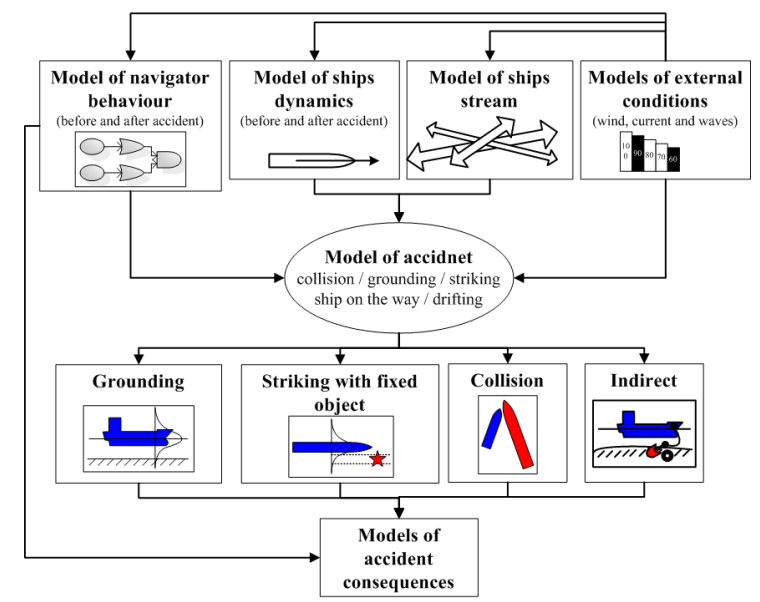

Fig. 6. Diagram of fully developed stochastic model of navigation safety assessment

Models of navigator behaviour, ships dynamics, ships stream and external conditions are developed on statistical data. Simulation works in fast time, therefore it is possible to achieve the statistical stability of the results. Positions of simulated groundings are presented in figure 7. 


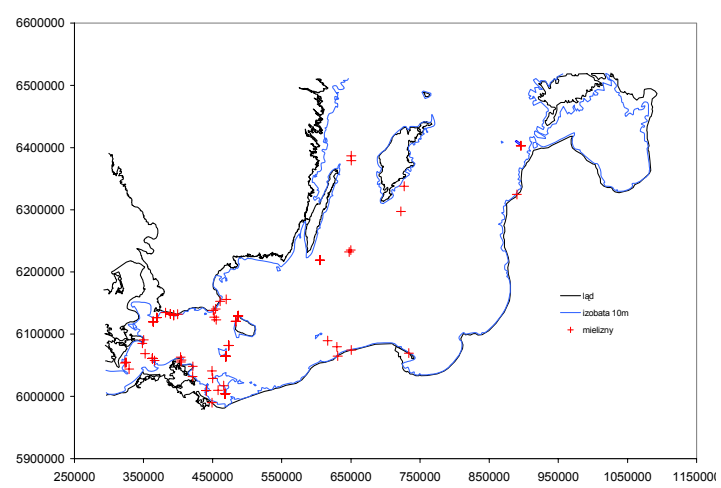

Fig. 7. Positions of simulated groundings (300 years)

\section{Summary}

The paper presents models of ships groundings on coastal waters. Models based on the fault trees are the most detailed. But therefore they are the most complicated and they need large number of data. Some of these data can not be established on the basis of statistical data. Presented model used in the simulation allows determining areas where the probability of grounding is highest. In the next step it is possible to develop the models of oil spills. The output of the model as the grounding places, ships involved, size of spill and navigational conditions could be useful for risk assessment of large sea areas.

\section{References}

1. Amrozowicz M. D.: Quantitative Risk of Oil Tanker Groundings. University of Florida, 1990.

2. Gucma L.: Risk Modelling of Ship Collisions Factors with Fixed Port and Offshore Structures. Akademia Morska Szczecin, 2005.

3. Hand, D. J.: Discrimination and Classification. Wiley \& Sons, New York, 1981.

4. Jebsen J. J.; Papakonstantinou V. C.: Evaluation of the Physical Risk of Ship Grounding. Massachusetts Institute of Technology. 


\section{MODELE WEJŚCIA NA MIELIZNĘ NA AKWENACH PRZYBRZEŻNYCH}

\section{Wstęp}

Rozwój transportu morskiego powoduje wzrost natężenia ruchu oraz zwiększenie się wymiarów statków. Rosnące zagrożenie związane $\mathrm{z}$ możliwością wystąpienia wypadków morskich spowodowało rozwój modeli pozwalających na ocenę bezpieczeństwa nawigacyjnego. Jednym $\mathrm{z}$ głównych czynników wpływających na bezpieczeństwo nawigacyjne jest prawdopodobieństwo wejścia statku na mieliznę. Do głównych typów modeli pozwalających na ocenę prawdopodobieństwa wejścia statku na mieliznę zaliczyć można modele oparte o:

- drzewa uszkodzeń,

- metody bayesowskie,

- prawdopodobieństwo geometryczne.

\section{Modele wejścia na mieliznę na akwenach przybrzeżnych}

\subsection{Drzewno uszkodzeń}

Konstrukcja drzewa uszkodzeń zaczyna się od uszkodzenia (wejścia na mieliznę), w następnych etapach uwzględnienia się wszystkie możliwe kombinacje zdarzeń, które mogą do niego doprowadzić. W każdym kolejnym etapie drzewa uszkodzeń ogólne przyczyny zajścia wypadku muszą być określone $\mathrm{w}$ tak szerokim zakresie, jak to tylko możliwe. Przedstawianie jak najbardziej ogólnych zdarzeń na każdym kolejnym etapie badań spowoduje, że praktycznie wszystkie możliwe kombinacje zdarzeń będą mogły być wzięte pod uwagę. Proces ten jest kontynuowany aż do momentu, gdy budujący drzewo uszkodzeń stwierdzi, że osiagnnięto taki stopień rozdzielności zdarzeń, który umożliwia oszacowanie prawdopodobieństwa zdarzeń elementarnych. Ogólny schemat drzewa uszkodzeń wejścia statku na mieliznę przedstawiony został na rysunku 1 . 


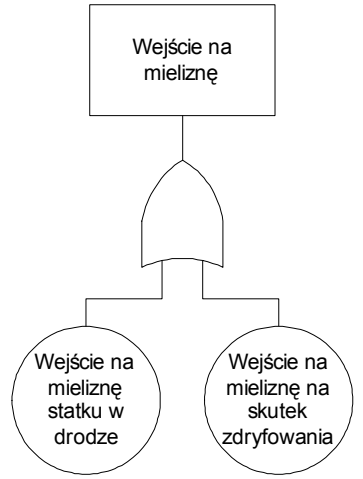

Rys1. Ogólny schemat drzewa uszkodzeń wejścia statku na mieliznę

Drzewo uszkodzeń wejścia na mieliznę statku w drodze przedstawione zostało na rysunku 2. Można zauważyć, że zdarzeniami prowadzącymi do wejścia na mieliznę statków $\mathrm{w}$ drodze są: błędy w planowaniu trasy lub błędy w procesie realizacji zaplanowanej trasy.

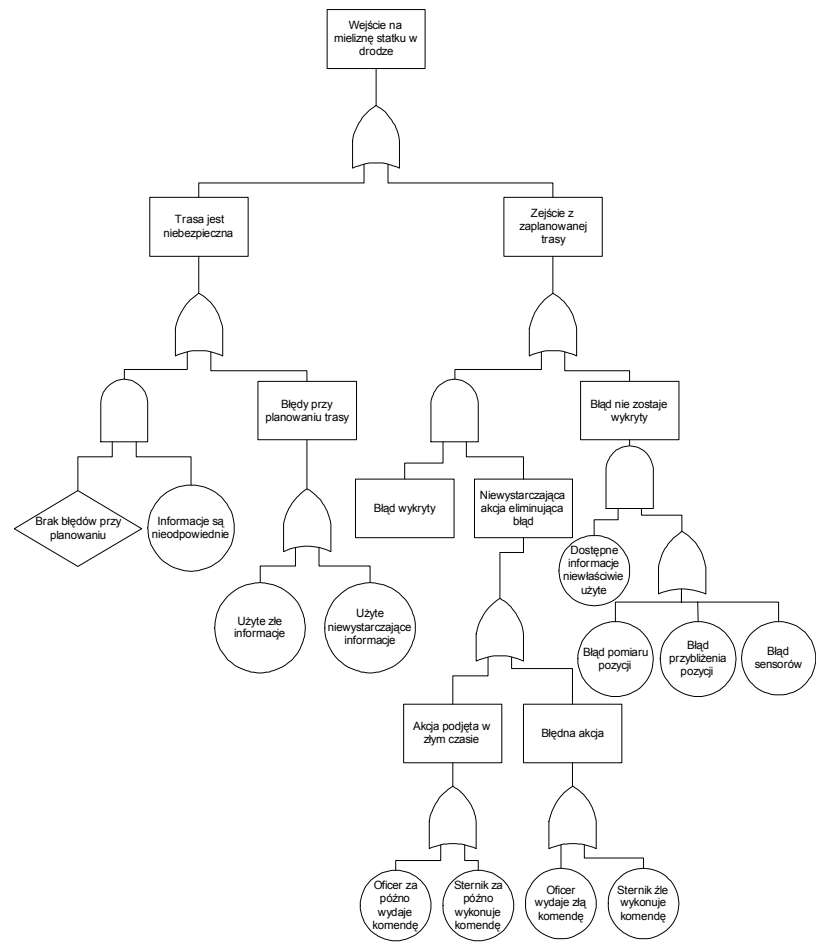

Rys.2. Drzewo uszkodzeń wejścia na mieliznę statku w drodze [1] 
Drzewo uszkodzeń wejścia statku na mieliznę na skutek zdryfowania przedstawia rysunek 3. Aby zdarzenie wejścia na mieliznę miało miejsce muszą zaistnieć wszystkie negatywne warunki:

- niebezpieczny wiatr i prąd - panujące wiatry i prądy muszą wywrzeć na statek taką siłę, aby skierować go na mieliznę,

- błąd asysty - jest to zarówno błąd wzywania pomocy, jak i błąd asysty, która miała pomóc $\mathrm{w}$ uniknięciu przez statek niebezpieczeństwa wejścia na mieliznę,

- uszkodzenie kotwicy - jest to uszkodzenie mające miejsce wówczas, gdy kotwica zostanie źle wyrzucona lub gdy kotwica nie utrzyma statku,

- utrata manewrowości - statek nie ma możliwości, aby utrzymać się na danym kierunku w wyniku utraty sterowności lub napędu.

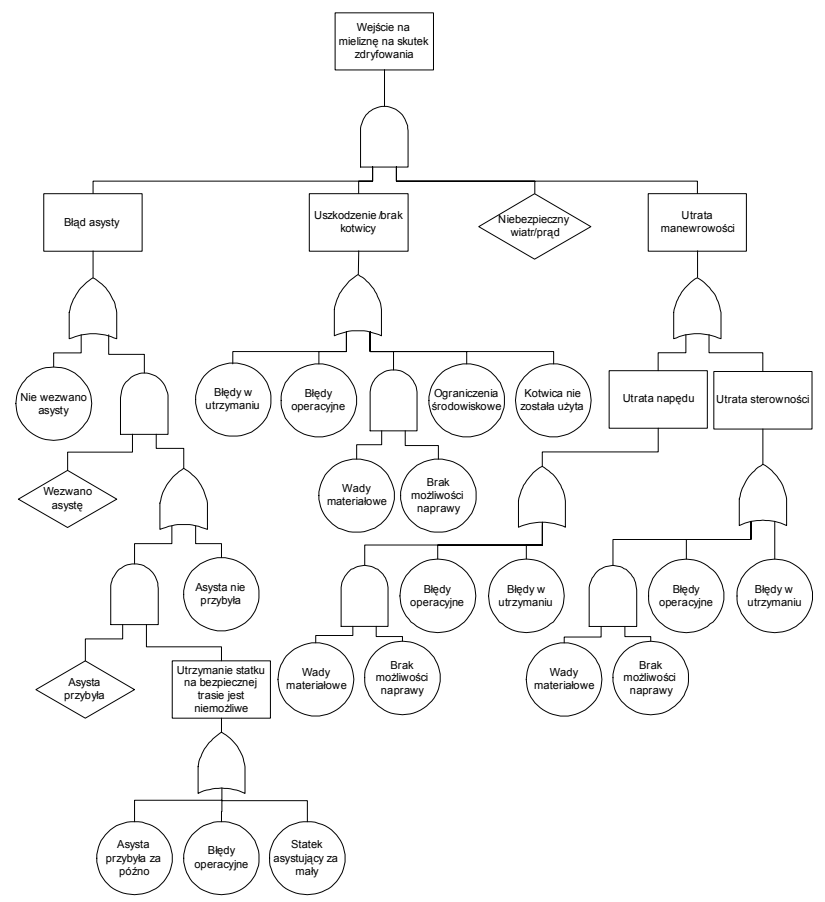

Rys. 3. Drzewo uszkodzeń wejścia statku na mieliznę na skutek zdryfowania [1]

W celu obliczenia prawdopodobieństwa wejścia na mieliznę należy obliczyć prawdopodobieństwa zdarzeń elementarnych, a następnie kolejno zdarzeń wyższego poziomu, aż do obliczenia prawdopodobieństwa zdarzenia końcowego. 


\subsection{Metody bayesowskie}

Ogólną tezą modelu jest założenie, że prawdopodobieństwo wejścia na mieliznę w poszczególnym przejściu statku zależy od czynników ryzyka lub zmiennych objaśniających. Formalnie model może być opisany w następujący sposób: niech $G$ oznacza przejście statku zakończone wejściem statku na mieliznę $\mathrm{i}$ niech $\mathrm{X}=\left(\mathrm{X}_{1}, \mathrm{X}_{2} \ldots \mathrm{X}_{\mathrm{p}}\right)$ oznacza zbiór zmiennych objaśniających. Zmienne te mogą być zarówno lingwistyczne, dyskretne jak i ciagłe. Celem modelu jest oszacowanie prawdopodobieństwa warunkowego zdarzenia $\mathrm{G}$, pod warunkiem zajścia zdarzenia x należącego do X. Zgodnie z twierdzeniem Bayesa, prawdopodobieństwo to może być obliczone według wzoru (1) [4]:

$$
p(G \backslash x)=\frac{l(x \backslash G) p}{l(x \backslash G) p+l(x \backslash S)(l-p)}
$$

gdzie: $p$ jest prawdopodobieństwem zajścia zdarzenia $G, l(x \mid G)$ i $l(x \mid S)$ sa prawd. zdarzenia $x$ pod warunkiem odpowiednio $G$ i $S, S$ oznacza zdarzenie bezpiecznego przejścia statku.

Aby obliczyć prawdopodobieństwo wejścia na mieliznę konieczne jest dokonanie wyboru zmiennych objaśniających [3] oraz określenie prawdopodobieństw $\mathrm{p}, 1(\mathrm{x} \backslash \mathrm{G})$ i $1(\mathrm{x} \backslash \mathrm{S})$. Zbiór zmiennych objaśniających $\mathrm{X}$ musi zawierać parametry przejścia statku, które moga mieć wpływ na prawdopodobieństwo wejścia statku na mieliznę. Te parametry to między innymi [4]:

- charakterystyka statku (zanurzenie, szerokość, zdolności manewrowe),

- parametry akwenu (głębokość, intensywność ruchu),

- warunki hydrometeorologiczne (wiatr, widzialność, prąd, falowanie),

- doświadczenie załogi,

- informacje o akwenie (aktualność map i informacji o pływach i prądach, VTS).

Wartości zmiennych objaśniających opisujących każdy parametr, mogą być określone na przykład na podstawie danych statystycznych. 


\subsection{Symulacja Monte Carlo}

Model został opracowany przy założeniu, że prawdopodobieństwo wejścia na mieliznę zależy od odległości do izobaty bezpiecznej (lub brzegu). Prawdopodobieństwo wejścia na mieliznę wyrażone jest wzorem (2):

$$
P_{G r}=P_{G} P_{H}
$$

gdzie: $P_{G r}$ oznacza prawdopodobieństwo wejścia na mieliznę, $P_{G}$ oznacza prawdopodobieństwo geometryczne, $P_{H}$ prawdopodobieństwo błędu człowieka.

Prawdopodobieństwo geometryczne jest obliczone na podstawie analizy rzeczywistego ruchu statków. Aby opisać ruch statków w pobliżu niebezpieczeństw zastosowany został specjalny rozkład kombinowany (rys. 4). Jest on złożeniem dwóch rozkładów normalnych o średniej równej zero.

$$
f(x)=\frac{1}{\sigma \sqrt{2 \pi}} \exp \frac{1}{2}\left(\frac{x}{\sigma}\right)^{2} \text { gdzie: } \sigma=\left\{\begin{array}{lll}
\sigma_{r} & \text { if } & x>0 \\
\sigma_{l} & \text { if } & x<0
\end{array}\right.
$$

gdzie: $\sigma_{r}$ oznacza odchylenie standardowe dla prawej strony rozkładu, $\sigma_{l}$ oznacza odchylenie standardowe dla lewej strony rozkładu.

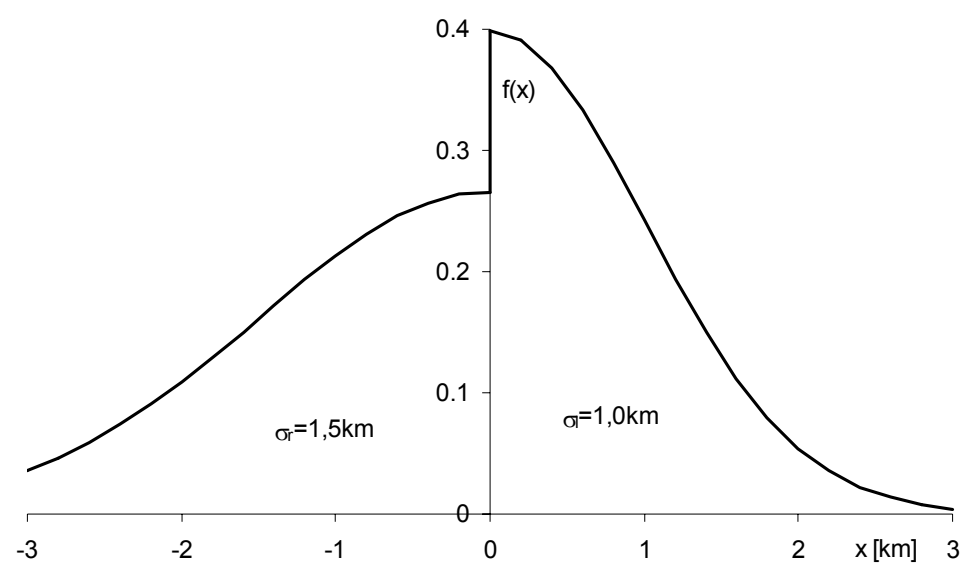

Rys. 4. Rozkład ruchu statków (kombinacja dwóch rozkładów normalnych) 
Dokonano analizy ruchu statków na Morzu Bałtyckim (dane rzeczywiste) i na akwenach ograniczonych (dane symulacyjne). Stwierdzono, że odchylenie standardowe zależy przede wszystkim od odległości od niebezpieczeństwa i od wielkości statku. Odchylenie standardowe może być obliczone przy użyciu zależności (4).

$\sigma=a D+b$

gdzie: $a, b$ oznaczają współczynniki regresji, $D$ oznacza odległość do niebezpieczeństwa (izobaty bezpiecznej).

Współczynnik a uzależniony jest od wielkości statku. W badaniach wielkość współczynnika a uzależniono od długości statku. Może on być obliczony na podstawie wzoru (5).

$a=-0.0002 L+0.12$

Współczynnik b przyjmuje wartości od 450 do 550, w dalszych badaniach przyjęto wartość średnią 500.

Typowe zachowanie się statków w okolicy Bornholmu przedstawione zostało na rysunku 5. Zauważyć można duże podobieństwo do zaproponowanego kombinowanego rozkładu normalnego.

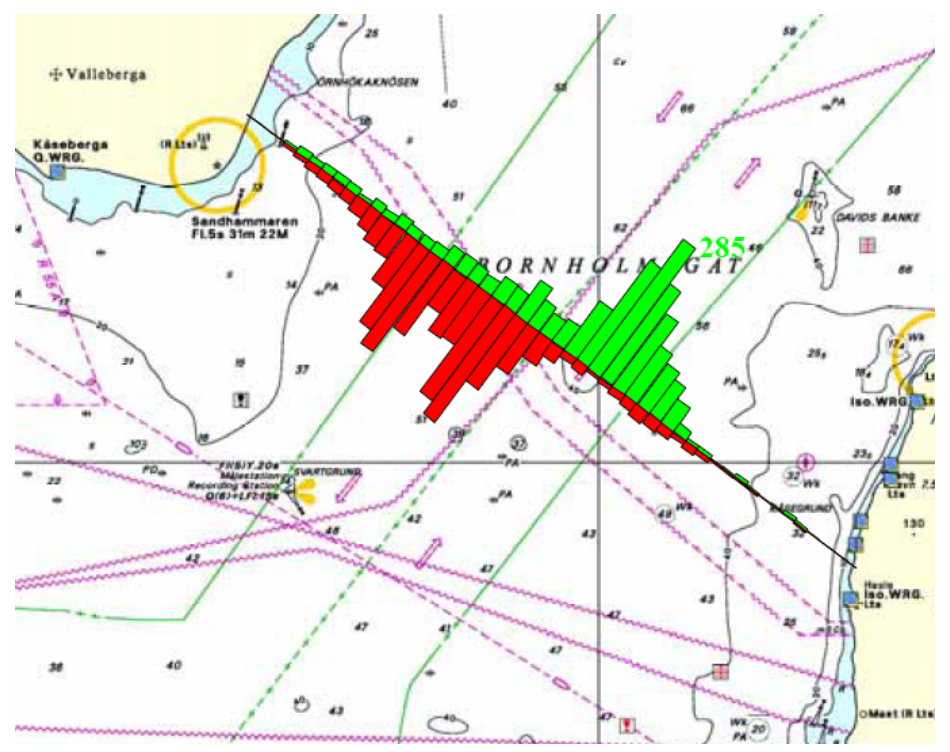

Rys.5. Rozkład ruchu statków, dane rzeczywiste z systemu AIS 
Prawdopodobieństwo błędu człowieka określone zostało na poziomie $\mathrm{P}_{\mathrm{H}}=1 \cdot 10^{-4}$, co jest typową wartością przyjmowaną w badaniach dotyczących błędów człowieka, potwierdzoną w szeregu badań dotyczących wejść statków na mielizny [2]. Ostatecznie prawdopodobieństwo wejścia na mieliznę obliczane jest przy użyciu wzoru (6).

$P_{G r}=P_{G r L}+P_{G r R}$

gdzie: $P_{G r R}$ oznacza prawdopodobieństwo wejścia na mieliznę $\mathrm{z}$ prawej strony, $P_{G r L}$ oznacza prawdopodobieństwo wejścia na mieliznę $\mathrm{z}$ lewej strony.

Tak obliczone prawdopodobieństwo wejścia na mieliznę wykorzystano w dalszych badaniach symulacyjnych wykorzystujących metodę Monte Carlo. Przykładowe wyniki tych badań przedstawione zostały w dalszej części artykułu.

\section{Przykładowe wyniki modelu wejścia na mieliznę zastosowanego w symulacji Monte Carlo}

Celem badań było określenie intensywności oraz symulowane pozycje wejść statków na mieliznę w rejonie południowego Bałtyku. Symulację przeprowadzono przy użyciu stochastycznego modelu oceny bezpieczeństwa nawigacyjnego (rys. 6).

Do budowy modeli zachowania się człowieka, dynamiki ruchu statków, strumieni ruchu statków oraz warunków zewnętrznych wykorzystane zostały dane statystyczne. Symulacja działa w czasie przyspieszonym, aby możliwe było osiagnięcie statystycznej stabilizacji wyników. Symulowane pozycje wejść statków na mieliznę przedstawione zostały na rys. 7. 


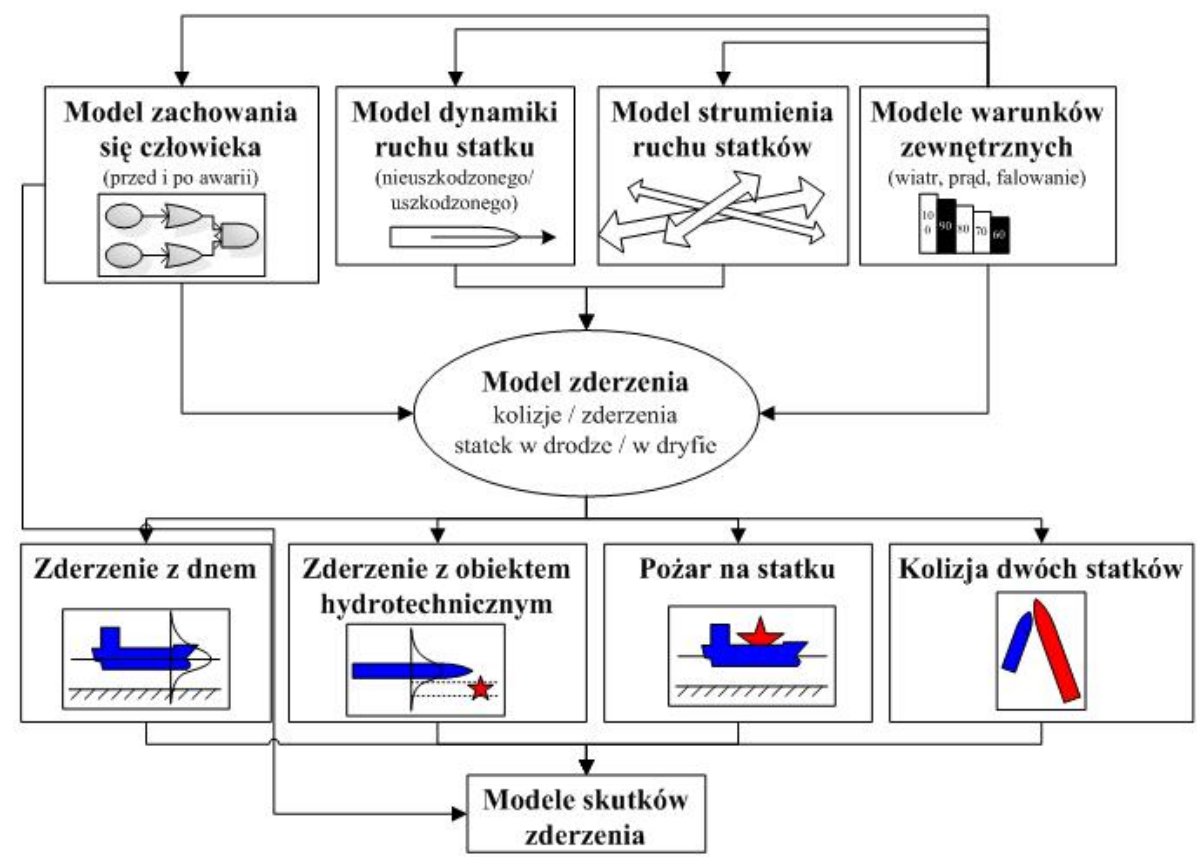

Rys.6. Diagram symulacyjnego modelu oceny bezpieczeństwa nawigacyjnego

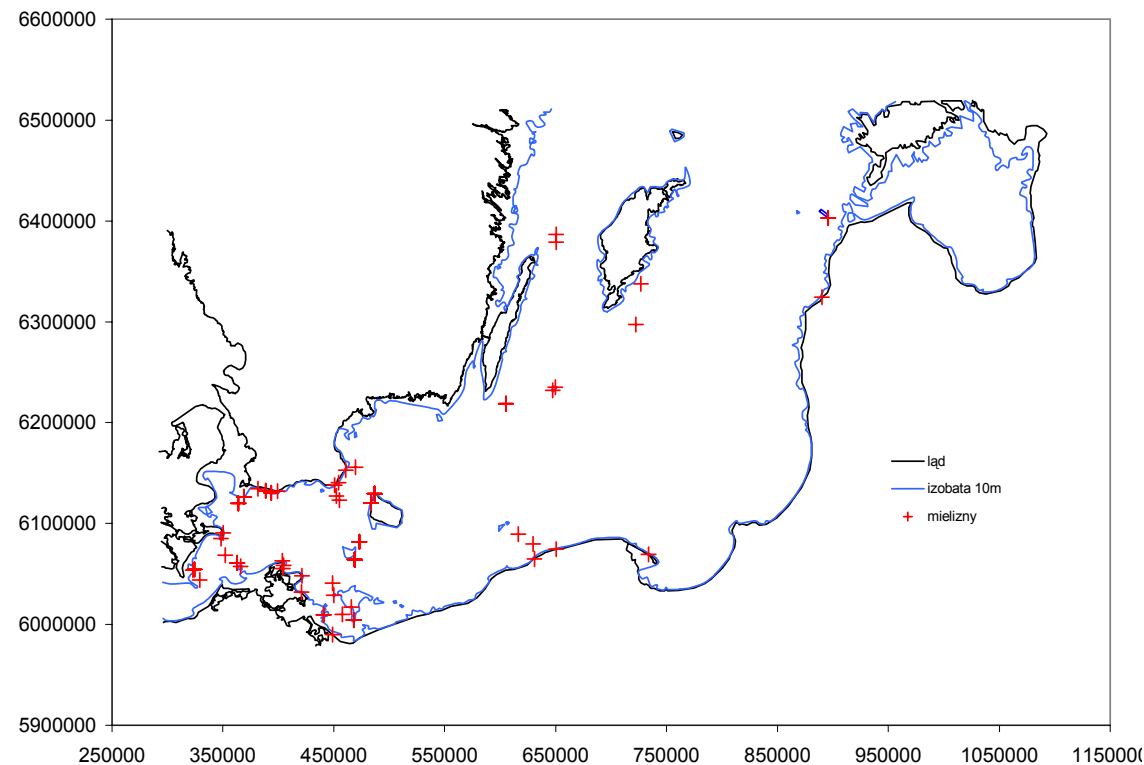

Rys. 7. Pozycje symulowanych wejść na mieliznę (300 lat symulacji) 


\section{Podsumowanie}

W artykule przedstawione zostały modele wejścia na mieliznę na akwenach przybrzeżnych. Najbardziej szczegółowym z przedstawionych modeli jest model oparty o drzewa uszkodzeń, jednak do jego budowy niezbędna jest bardzo duża liczba danych. Części z nich nie można określić na podstawie danych statystycznych. Zastosowanie modeli wejścia na mieliznę $w$ symulacji pozwala na wyznaczenie obszarów, na których dochodzi do największej ilości wejść na mieliznę. W dalszym kroku możliwa jest budowa modelu pozwalającego na obliczenie wielkości rozlewów. Wyniki modelu takie jak pozycje wejść na mieliznę, dane statków, wielkości rozlewów mogą być przydatne do oceny ryzyka dużych obszarów morskich.

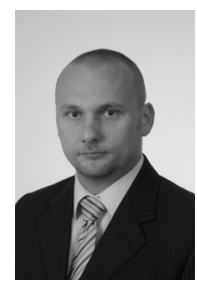

Marcin Przywarty (MSc) is research and teaching employee of Szczecin Maritime University. His main scientific interest involves probabilistic methods in ships safety assessment. He is an author of several scientific publications. 